\title{
VÝSLEDKY ARCHEOBOTANICKÝCH ANALÝZ Z LOKALITY KOMJATICE-KŇAZOVA JAMA V KONTEXTE LATÉNSKYCH SÍDLISK ZO SLOVENSKA
}

\author{
Michaela Látková - Peter Horváth
}

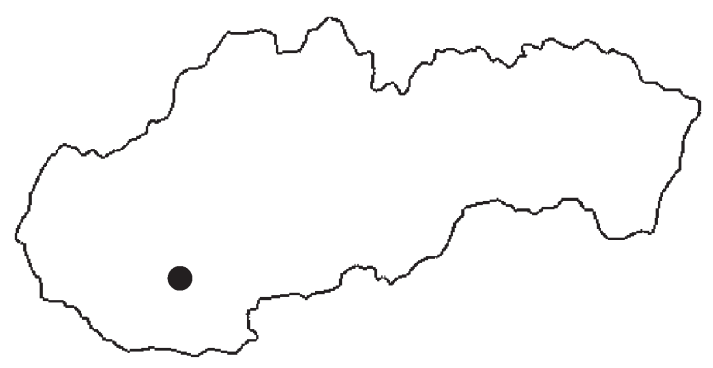

DOI: https://doi.org/10.31577/szausav.2021.68.3

Keywords: Komjatice, La Tène period, archaeobotany, settlement, cereals, wild plants

\begin{abstract}
The results of archaeobotanical analysis from the site Komjatice-Kňazova jama in the context of La Tène settlements from Slovakia

The main goal of this study is to analyse and the interpretation of plants macro remains files from La Tène localities of southwestern Slovakia with an emphasis on the Komjatice-Kňazova jama site. The obtained results were confronted with each other, a series of different types of analyses were also applied to the researched material, especially to clarify the issue of the relationship of lower settlements to upland localities, oppids. The obtained and presented archaeobotanical findings indicate certain different trends in crop popularity depending on regions or chronological degrees. When comparing the examined set of planting species from the sample from Komjatice-Kňazova jama with the findings from other settlements, it can be stated that they represent a typical composition with not significantly difference from other sites. Also, the current findings do not indicate that the inhabitants living in fortified, highland localities have different or food strategies other than those living in lowland unfortified settlements.
\end{abstract}

\section{ÚVOD}

Obec Komjatice sa nachádza v novozámockom okrese na juhozápadnom Slovensku. V jej katastri sa na riečnych nivách a sprašových terasách nachádza viacero archeologických lokalít. V spojitosti so stavebnými aktivitami (závlahový systém, ropovod, štrkovisko atd’.) sa tu uskutočnilo viacero záchranných archeologických výskumov. Vd’aka nim sa v polohe Kňazova jama podarilo preskúmat’ a zdokumentovat’ aj čast’ laténskeho sídliska. Celkovo sa podarilo nájst’ šest' zahĺbených obytných objektov a jednu bližšie nešpecifikovanú „,kultúrnu“ jamu. Archeologický materiál bol v 80. rokoch len čiastkovo publikovaný (Točík 1980b, 219, 220, obr. 127-129; 1981, 141-143). Najnovšie bol nálezový fond revízne spracovaný a súborne publikovaný $P$. Horváthom (2014). Komplexnou syntézou všetkých analyzovaných chronologických aspektov dospel autor $\mathrm{k}$ chronologickému zaradeniu skúmaného sídliska do rozmedzia stupňov LTB2/C1 až po záver stupňa LTC1, ktorý zrejme neprekračuje (Horváth 2014, 78).

Cielom príspevku je primárne prezentovat výsledky archeobotanickej analýzy rastlinného materiálu z lokality Komjatice-Kňazova jama a definovat’ spektrum úžitkových rastlín (pestovaných aj planorastúciach) na základe hodnotenia nálezov zuholnatených semien, ako aj odtlačkov rastlín na mazaniciach. Následne tieto výsledky porovnat’ s inými podobnými lokalitami. V prvom kroku analýzy bola pozornosṫ venovaná hladaniu trendov vo výskyte rastlinných druhov, resp. typov nálezov (semená a plevy) na jednotlivých lokalitách. V neposlednom rade bola snaha diskutovat o podobnostiach, resp. rozdieloch $\mathrm{v}$ archeobotanických nálezoch plodín medzi výšinnými opevnenými a nížinnými neopevnenými laténskymi lokalitami na Slovensku. Pre toto porovnanie boli využité len staršie publikované dáta rastlinných makrozvyškov (d’alej len RMZ), pričom vzorky na archeobotanickú analýzu boli v minulosti často odoberané bez systematického prístupu. Možno konštatovat' (ako v prípade vzorky z Komjatíc), že šlo náhodné alebo o cielené odoberanie vzoriek z výnimočných kontextov, kde sa predpokladala alebo bola zjavná prítomnost' rastlinného materiálu. Preto je nutné pri interpretácií získaných dát mat' na zreteli túto skutočnost', ktorá mohla do istej miery nadhodnotit’, resp. podhodnotit skutočný stav. 
Ešte v nedávnej minulosti boli oppidá, predovšetkým na základe bohatej materiálnej kultúry, považované za vrchol vývoja v rôznych spektrách života laténskej spoločnosti, ktoré predstavovali sídla špecifickej časti populácie závislé na dovoze základných potravín z nížinných osád v ich zázemí (Collis 2000, 236; Küster 1991, 426, 427; 1993; Wells 1993, 139; Woolf 1993, 214). V súčasnej archeologickej literatúre vidiet značný trend odklonu od tejto predstavy a prevažuje názor, že nížinné vidiecke osady a výšinné centrá (oppidá) mali plnohodnotne rozvinutú produkciu polnohospodárskych plodín. Lokálne prípadové štúdie, ktoré by na rastlinnom materiáli testovali tieto hypotézy, vychádzajú predovšetkým z pramennej bázy oppíd (Danielisová/Hajnalová M. 2014) alebo výšinných opevnených sídlisk (napr. Hajnalová M. 1999). Avšak pre verifikáciu tejto hypotézy je nutné skúmat aj materiál z bežných vidieckych lokalít, ktoré sa nachádzajú v okolí oppíd a následnou konfrontáciou výsledkov z oboch sídelných typov je možné priblížit sa k objektívnejšiemu obrazu produkcii a distribúcii polnohospodárskych plodín v dobe laténskej.

\section{MATERIÁL A METODIKA PRÁCE}

\section{Materiál}

\section{Archeobotanika}

Skúmaný sediment predstavuje jedna vzorka zeminy (uloženiny), ktorá bola odobraná na lokalite Komjatice-Kňazova jama počas záchranného výskumu pod vedením A. Točíka z AÚ SAV v Nitre. V dokumentácii sa, žial', nezachovali podrobnejšie správy o metodike a účele odobranej vzorky. Zachoval sa len popis na papierovom vrecku, v ktorom bola zemina uskladnená. Podla neho je zrejmé len to, že pochádzala z objektu (chaty) XI bez bližšej lokalizácie. Ide o mierne zahĺbený obdížnikový objekt, chatu s rozmermi $440 \times 300 \mathrm{~cm}$, s híbkou $40 \mathrm{~cm}$. Objekt mal orientáciu Z-V a pri kratších stenách bol lemovaný kolovými jamami. Tie sa však nachádzali aj pozdíž stredovej osi objektu, ktorý obsahoval pomerne vela kremnického materiálu (29 937 g). Okrem keramiky sa nachádzali vo výplni objektu fragmenty tkáčskych závaží, hlinené prasleny, kamenný brúsik a fragmenty sapropelitových náramkov (Horváth 2014, 70, 71; tab. XIII). Tento objekt spolu s dalšími piatimi patril zrejme len k čiastočne odkrytému sídlisku zo strednej doby laténskej LTB2/C21 (Horváth 2014, 77; Točík 1980b, 219). V tomto objekte sa ako v jedinom na celom sídlisku podarilo zdokumentovat zvyšky po vykurovacom zariadení v podobe menšej kupolovitej piecky, vyvýšenej nad úrovňou podlahy (Horváth 2014, 73). Vzhl’adom na charakter sedimentu vzorky (popol) je možné predpokladat', že hodnotený materiál pochádza práve z blízkosti tohto zariadenia.

Po preplavení a analýze zachovaného organického materiálu bolo možné konštatovat', že všetky RMZ boli konzervované výlučne karbonizáciou (zuholnnatením). V rastlinnom materiáli sa aj napriek vysokej fragmentárnosti podarilo identifikovat obilné zrná, fragmenty obilných pliev, fragmenty strukovín aj semená planorastúcich druhov.

\section{Mazanice}

Fragmenty mazaníc, ktoré boli taktiež podrobené archeobotanickej analýze, pochádzajú rovnako zo sídliskového objektu (chaty XI). V nálezovom súbore sa celkovo nachádzalo 15 kusov fragmentov mazaníc. Skúmaných bolo celkovo len pät kusov, na ktorých sa podarilo objavit odtlačky RMZ. Tento súbor bol rozšírený o nálezy fragmentov tkáčskych závaží (chata XI) v celkovom počte 11 kusov. Odtláčanie zvyškov RMZ do plastelíny v hmote týchto závaží nebolo úspešné, nakol'ko sa zmes sušenej (resp. slabo vypálenej?) hliny príliš drobila a dochádzalo k deštrukcii viditelne zachovaných stôp jednotlivých RMZ. $\mathrm{Z}$ uvedených dôvodov sa pristúpilo len $\mathrm{k}$ hodnoteniu negatívnych odtlačkov, najmä fragmentov stebiel pestovaných, ale aj planorastúcich druhov.

\section{Metodika extrakcie rastlinných makrozvyškov}

Skúmaný sediment mal popolovitý charakter, pričom spočiatku na základe vizuálneho hodnotenia nebola zaznamenaná vyššia prítomnost’ rastlinného materiálu. Vzhl'adom na značne dlhú dobu uloženia vzorky v depozitári bol sediment výrazne vysušený a musel byt pred preplavením namočený. Objem vzorky bol pät litrov. 
Pre extrakciu rastlinných makrozvyškov zo vzorky bola využitá metóda ručného premývania wash - over (Hajnalová/Hajnalová 1998). Pri tejto technike bol rastlinný materiál zachytávaný na sito s rozmermi ôk $0,25 \mathrm{~mm}$. Zostatkový sediment po preplavení, tzv. taažká minerálna frakcia, bol následne vizuálne skontrolovaný na prítomnost' RMZ, ktoré sa nepodarilo nájst pri preplavení materiálu. Táto frakcia bola usušená spolu s prachovými časticami, ktoré boli d’alej spolu s preplavenými frakciami laboratórne skúmané. V tažkej frakcii sa okrem drobných keramických fragmentov nachádzali aj zvieracie kosti, rybie šupiny a ulity mäkkýšov (1-2 mm vel'ké).

\section{Metóda laboratórnej analýzy}

Laboratórne bol analyzovaný celý získaný objem oboch preplavených frakcií (lahkej i tažkej). Identifikácia a klasifikácia RMZ bola prevedená pomocou stereoskopickej lupy Zeiss Discovery V8 s maximálnym zväčšením 40 x, na Katedre archeológie FF UKF v Nitre.

Pre klasifikáciu nálezov obilnín boli použité identifikačné kritériá podla E. Hajnalovej (1993) a S. Jacomet (2006). Pre identifikáciu a klasifikáciu planorastúcich taxónov boli využité základné atlasy semien (Anderberg 1994; Berggren 1969; 1981).

\section{Metodika získavania odtlačkov z mazaníc}

Tam, kde to tvrdost̉ materiálu dovolovala, spočívala metóda analýzy odtlačkov rastlinných zvyškov z mazaníc v hodnotení „pozitívov“ semien a iných častí rastlín získaných odtláčaním do plastelíny. U artefaktov z drobivého materiálu (závažia) boli hodnotené priamo negatívy odtlačkov v samotnej hmote artefaktov. Na niektorých fragmentoch bolo možné pozorovat detaily konštrukčných systémov. Tieto informácie boli taktiež zaznamenávané a d’alej využité pri 3D rekonštrukcii objektu (Horváth/Látková 2014). Detailnejšie však boli hodnotené aj faktory ako vel'kost', hladenie, prítomnost’ a zloženie organickej hmoty obsiahnutej v mazanici. Zaznamenané boli pritom aj údaje o farbe výpalu a hmotnost̉ jednotlivých fragmentov. Najväčšia pozornost̉ bola primárne venovaná identifikácii a klasifikácii zaznamenaných organických rastlinných makrozvyškov.

\section{VŠEOBECNÉ VÝSLEDKY}

\section{Archeobotanika}

Vd’aka priaznivej polohe sídliska Komjatice-Kňazova jama na okraji nivy rieky Nitra sa tu koncentrovalo osídlenie od najstarších období polnohospodárskeho praveku (Točík 1978, 252, 253; 1980a, 215-229; 1980b, 266-272; 1981, 139-157). Rozsiahle osídlenie a bohatý nálezový materiál dal podnet aj pre archeobotanické skúmanie týchto pravekých archeologických štruktúr. Predovšetkým išlo o antrakologickú analýzu uhlíkov, ktoré boli získané bez využitia preplavovacích techník. ${ }^{1}$

Archeobotanický materiál z laténskej fázy osídlenia lokality bol získaný zo vzorky s pomerne malým objemom odobraného sedimentu. Napriek tomu sa za pomoci ručného premývania podarilo získat pomerne rozsiahly súbor 768 zuholnatených rastlinných nálezov (semien a pliev). Vzhladom na vysoký počet nálezov a malý objem preplaveného sedimentu je priemerná hustota nálezov na jeden liter sedimentu pomerne vysoká a predstavuje 153,6 RMZ/l. Na základe takto vysokej priemernej hustoty nálezov, možno predpokladat', že ide o koncentráciu, ktorá bola zámerne a v pomerne krátkom čase deponovaná a pravdepodobne predstavuje jednu archeologickú udalost' (Hajnalová M. 2012, 95; Willerding 1971).

\section{Pestované plodiny}

V skúmanej vzorke sa podarilo zachytił až pozoruhodne široké spektrum pestovaných plodín (obilnín a strukovín). Pestované plodiny, $\mathrm{v}$ tomto prípade najmä obilniny, tvoria $\mathrm{v}$ skúmanom súbore najväčší podiel spomedzi analyzovaných RMZ. Nálezy 503 obilných zŕn dokladajú pomerne široké spektrum využívaných

1 J. Mihályiová, ústna informácia z roku 2014. 
obilnín (6 druhov; tabela 1). Najpočetnejšou obilninou je plevnatý jačmeň siaty. Sortiment obilnín d’alej reprezentujú nálezy prosa siateho, pšenice špaldovej, pšenice jednozrnovej a pestovaného ovsa siateho. Vzorka obsahuje plodiny známe z doby laténskej na území Slovenska (Hajnalová E. 1993; 1989). Výskyt druhov, ktoré spolu nemohli $\mathrm{v}$ jednom čase rást’ na poli indikuje zmiešaný charakter nálezov. $\mathrm{K}$ takémuto zmiešaniu došlo zrejme $\mathrm{v}$ čase pred alebo počas ich depozície.

Túto skutočnost̉ podporuje aj fakt, že v súbore sa vyskytli plodiny vysievané na jeseň (raž, no pravdepodobne i jačmeň a pšenice) a na jar (proso a ovos). Žial', vzhladom na zmiešaný charakter vzorky, t. j. zmes plodín s rôznymi ekologickými požiadavkami na svoje stanovište, nie je možné stanovit', ktoré polné buriny sprevádzali jednotlivé plodiny, a tak ich využit na determináciu času výsevu plodín, ktoré v dobe laténskej mohli byt’ pestované ako oziminy a jariny.

Istým špecifikom $\mathrm{v}$ rámci pestovaných plodín je prítomnost̉ pšenice jednozrnovej, ktorej zrná možno na základe identifikačných kritérií (Kreuz/Boenke 2002; v. Zeist 1999; Willcox 2003) klasifikovat' ako dvojzrnovú - pšenicu jednozrnovú (Triticum monococcum, angl. two-grained einkorn). Tento druh bol doposial' len sporadicky pozorovaný $\mathrm{v}$ archeobotanických záznamoch z územia dnešného Slovenska. ${ }^{2}$ Napriek tomu možno predpokladat jej výskyt aj na iných lokalitách, a to nielen v mladšej dobe železnej, ale najmä $\mathrm{v}$ starších pravekých obdobiach. V minulosti nebola táto varieta často rozpoznaná a takéto nálezy boli často mylne pripisované $\mathrm{k}$ pšeniciam jednozrnovým alebo dvojzrnovým. ${ }^{3}$ Dvojzrnová pšenica jednozrnová je na základe súčasného stavu poznania známa predovšetkým z oblastí Blízkeho východu a Balkánu. Z chronologického hladiska sa výskyt tejto pšenice datuje najmä do obdobia neolitu (Kreuz/Boenke 2002; v. Zeist 1999; Willcox 2003). ${ }^{4}$

Pomerne vysoký podiel, až 65 \% z celkového počtu obilnín, tvoria fragmenty, ktoré nebolo možné na základe identifikačných kritérií klasifikovat do užších kategórií (do rodu). Túto fragmentárnost rastlinného materiálu zrejme spôsobili preddepozičné procesy, ktoré sa podielali na konzervácií materiálu, napr.: horenie, RMZ sa pravdepodobne nachádzali v chlebovej peci v danom objekte (Horváth 2014, 71-73).

Sortiment pestovaných plodín rozširujú strukoviny, ktoré reprezentujú dva druhy, a to šošovica siata (1 kus) aj hrach siaty (1 kus). Sú to bežné druhy aj na ostatných lokalitách doby laténskej, ale aj v celom pravekom a včasnostredovekom období, kde bol sediment odoberaný na archeobotanické analýzy (Hajnalová E. 1989).

\section{Obilné plevy}

Vzorka obsahovala aj pomerne bohatý súbor obilných pliev (93 kusov; tabela 2), ktorý z percentuálneho hladiska tvorí $12 \%$ všetkých RMZ. Nálezy obilných pliev nie sú ničím výnimočné na archeologických lokalitách. Plevy sa objavujú vo všetkých pravekých archeologických kultúrach, ktoré pestovali plevnaté pšenice. Je to kvôli tomu, že tieto druhy pšeníc boli zvyčajne uskladnené v plevách (Kreuz 2005, 129; Nesbitt/ Samuel 1996). Medzi hlavné pestované obilniny v laténskom období patrili predovšetkým pšenica
Tabela 2. Komjatice, poloha Kňazova jama. Zoznam obilných pliev.

\begin{tabular}{|l|c|c|}
\hline \multirow{2}{*}{ Obilné plevy } & \multicolumn{2}{c|}{ Spolu RMZ } \\
\cline { 2 - 3 } & Def. & Cf. \\
\hline Avena sativa & 1 & - \\
Triticum monoccocum glume bases & 7 & 3 \\
Triticum monococcum (two-grained) glume bases & 16 & - \\
Triticum spelta glume bases & 11 & 15 \\
Rachis internode Hordeum/Triticum & 4 & - \\
Indet & 36 & - \\
\hline Spolu & \multicolumn{2}{|c|}{93} \\
\hline
\end{tabular}

2 M. Hajnalová, ústna informácia z roku 2014.

3 Za milé poskytnutie odborných rád pri klasifikácií a interpretácií RMZ d’akujeme M. Hajnalovej z Katedry Archeológie FF UKF v Nitre. Ústna informácia z roku 2014

4 Dvojzrnové klásky sa však pomerne bežne vyskytujú aj dnes u niektorých krajinských odrôd spravidla jednozrnovej jednozrnky (Hajnalová/Dreslerová 2010). 


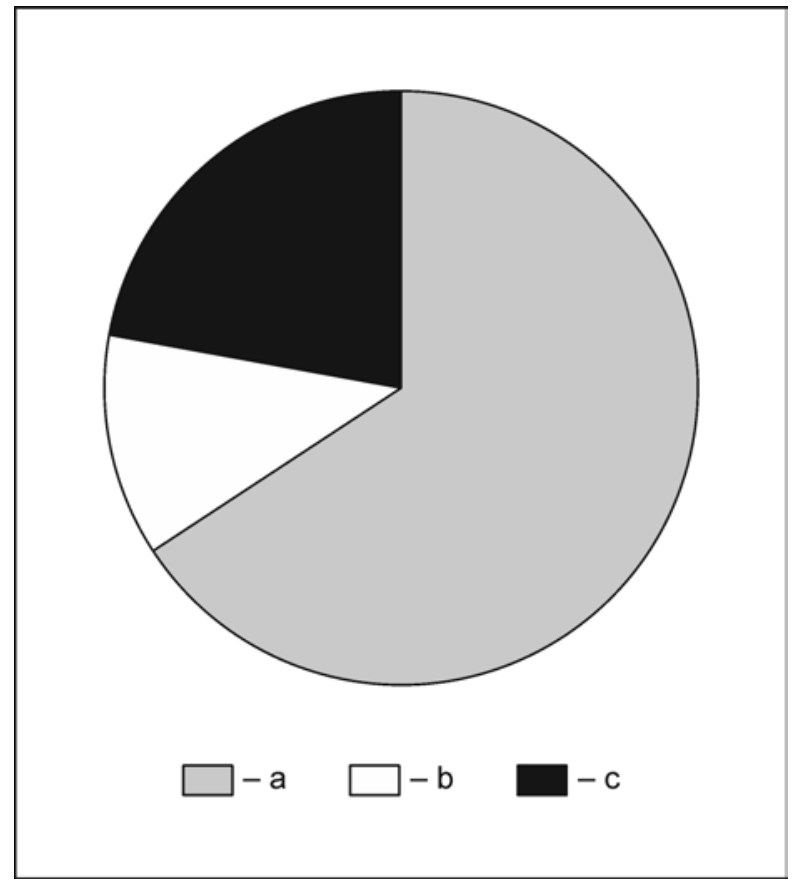

Obr. 1. Komjatice, poloha Kňazova jama. Pomer hlavných komponentov (pestované plodiny, plevy a planorastúce druhy). Legenda: $\mathrm{a}$ - pestované plodiny; $\mathrm{b}$ - obilné plevy; c - planorastúce druhy. špaldová a pšenica dvojzrnová (Hajnalová E. 1993, 96, 115-118; 1989; Kočár/Dreslerová 2010, 222). Oba menované druhy sa vyznačujú pomerne masívnymi plevami, ktoré umožňujú lepšie zachovanie diagnostických znakov. Vdaka nálezom pliev je možné tieto druhy v skladbe determinovat. Bohužial', plevy sa nemusia nachádzat’ vždy na lokalite, pretože spravidla sa t’ažšie zachovávajú, t. j. zhoria bez zvyšku pri nižších teplotách ako obilné zrná tých istých plodín (Boardman/Jones 1990).

Práve počas doby laténskej dochádza k pomerne výrazným zmenám v skladbe pestovaných obilnín, ktoré súvisia $\mathrm{s}$ nástupom nových, tzv. „sekundárne" domestikovaných obilnín. Medzi nich patrí raž siata a ovos siaty (Hajnalová E. 1993, 62-71, 85-90). Problémom pri archeobotanickej identifikácí́ semien ovsa siateho je, že samotné zrná sa nedajú jednoznačne odlíšit od planej formy (napr. Avena fatua alebo Avena strigosa). Pestovanú formu ovsa od jeho planých variet možno explicitne odlísit len na základe morfológie báz kvetných pliev (angl. floret base) ovsa (Hajnalová E. 1993, 85; v. Zeist 1968). Plevy ovsa sa však zachovávajú len vo výnimočných prípadoch preto, že ovos sa radí k nahozrnovým obilninám (zrno sa z pliev pri mlátení uvolňuje samovol’ne) a jeho plevy sú

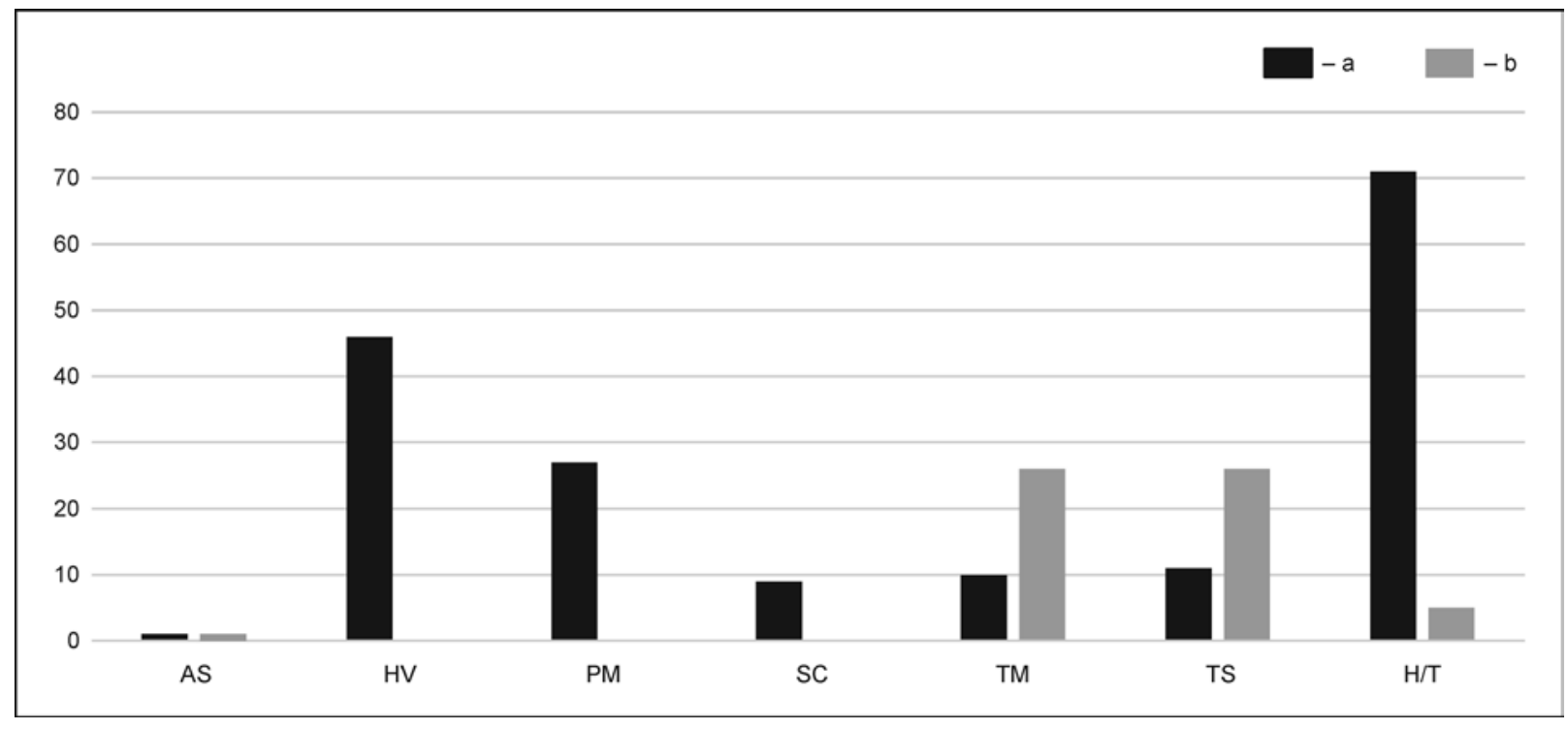

Obr. 2. Komjatice, poloha Kňazova jama. Pomer hlavných komponentov vybraných konkrétnych druhov (pestované plodiny a obilné plevy). Legenda: AS - Avena sativa; HV - Hordeum vulgare; PM - Panicum miliaceum; SC - Secale cereale; TM - Triticum monococcum; TS - Triticum spelta; H/T - Hordeum/Triticum; a - obilniny; b - plevy.

fragilné. V skúmanej komjatickej vzorke sa podarilo identifikovat nález bázy kvetnej plevy ovsa siateho (Avena sativa sensu stricto; tabela 2). Na základe tohto nálezu možno predpokladat, že i nájdené zrno ovsa $\mathrm{s}$ vyššou pravdepodobnostou patrilo k pestovanej domestikovanej forme.

Okrem tohto sa vo vzorke podarilo identifikovat viacero d’alších báz kvetných pliev, tie však patrili pšenici jednozrnovej a špaldovej. Bázy pliev pšenice jednozrnovej patrili ako „klasickej“ forme jednozrnovej 
jednozrnky, tak dvojzrnovej forme pšenice jednozrnovej (determinované na základe Kreuz/Boenke 2002; v. Zeist 1999; Willcox 2003).

Komplexné porovnanie zastúpenia pestovaných plodín (semien a pliev) a planorastúcich druhov dokladá nadpolovičnú väčšinu pestovaných druhov, z čoho najpočetnejšiu skupinu tvoria jednoznačne obilniny (obr. 1).

Pomerne vysoký percentuálny podiel burín a pliev vo vzorke, ktorý predstavuje 34 \%, vytvára predpoklad, že analyzovaný súbor RMZ možno považovat' za zmes odpadov a produktov (prípadne medziproduktov) z procesu pozberovej úpravy plodín. Tie boli v konečnom štádiu spálené (Bogaard 2004, 67, 68; Hajnalová M. 2012, 89; v. der Veen 1992, 81).

Pomer nájdených obilných zŕn a pliev (obr. 1;2) u jednotlivých plodín dokladá, že v skúmanom súbore RMZ majú $\mathrm{v}$ absolútnom počte nálezov prevahu nálezy plevnatých pšeníc (napr. Triticum monococcum a Trtiticum spelta). V súbore sa nevyskytujú nálezy pliev či klasových vretien nahozrnových obilnín (Secale cereale a Hordeum vulgare-vulgare). Všetky plodiny môžu predstavovat rovnaký produkt či fázu, napr. nevymlátené, v peci sušené klasy, ale z dôvodu neschopnosti prežit vyšší žiar, boli plevy nahozrnových obilnín spálené bez zvyšku. Podobne to môže byt' (medzi) produkt nepreviaty no vymlátený.

\section{Planorastúce druhy}

V skúmanej vzorke sú zastúpené aj planorastúce druhy (tabela 3). Z hladiska druhového zloženia prevažovali najmä polné buriny (Dostál/Červenka 1991; 1992), ktoré sa pravdepodobne do antropogénnych uloženín dostali ako odpad po procese spracovania obilnín (Jones 1984). V skúmanom súbore polných burín boli doložené druhy, spájajúce sa s jarným (napr. Neslia paniculata) či jesenným (napr. Agrostemma githago) výsevom. Okrem polných burín boli vo vzorke doložené aj druhy z iných biotopov a stanovišté. Na základe RMZ nálezov je možné v zázemí lokality potvrdit existenciu a exploatáciu trvalých trávnatých porastov (napr. Hypericum maculatum), prípadne obnažené dná vodných tokov (Xanthium strumarium). Prítomnost' ruderálnych stanovíšte, polných okrajov a ciest dokladali nálezy RMZ patriacich k druhu bazy chabzdovej.

\section{Mazanica}

Analýzy odtlačkov dokladajú predovšetkým prítomnoste plevnatých pšeníc, a to najmä pšenice špaldovej, ktorej plevy (3 kusy) boli identifikované na dvoch fragmentoch. $Z$ okruhu nechlebových plodín bol identifikovaný odtlačok semien prosa siateho (1 kus). Vo väčšej miere boli prítomné odtlačky tiel planorastúcich druhov rastlín, avšak nedisponovali charakteristickými prvkami, na základe ktorých by ich bolo možné identifikovat', zväčša šlo len o odtlačky častí stebiel. Čo sa týka identifikovaného sortimentu pestovaných plodín zaznamenaných na mazaniciach možno konštatovat', že identifikované druhy boli doložené aj v súbore RMZ (tabela 4).

Nálezy pliev v mazaniciach z Komjatíc sú na rozdiel od slamy pomerne zriedkavé. Obilné plevy, získané pri procese spracovania obilnín, nemuseli byt’ považované za odpad. Ich využitelná hodnota mohla byt’ ovel’a vyššia, a to napr. ako krmivo, alebo podstielka pre zvieratá (v. der Veen 1999). Je možné uvažovat', resp. je vysoko pravdepodobné, že v dobe laténskej boli známe negatívne vplyvy rôznych
Tabela 3. Komjatice, poloha Kňazova jama. Planorastúce druhy.

\begin{tabular}{|c|c|c|c|}
\hline \multirow{2}{*}{ Planorastúce druhy } & \multicolumn{2}{|c|}{ Spolu RMZ } & \multirow{2}{*}{ Stanovište } \\
\hline & Def. & Cf. & \\
\hline Agrostemma githago & 1 & - & pole \\
\hline Bromus arvensis & 1 & - & pole \\
\hline Bromus secalinus & 2 & - & pole \\
\hline Bupleurum rotundifolium & 1 & - & pole \\
\hline Echinochloa crus-galli & 6 & - & pole \\
\hline Echium vulgare & 1 & - & lúka \\
\hline Galium aparine & 1 & - & pole \\
\hline Galium spurium & 1 & - & pole \\
\hline Hypericum maculatum & 1 & - & lúka \\
\hline Chenopodium album agg. & 114 & - & okraj polí/reuderál \\
\hline Chenopodium hybridum & 11 & - & okraj polí/reuderál \\
\hline Neslia paniculata & 1 & - & pole \\
\hline Sambucus ebulus & 8 & - & okraj polí/reuderál \\
\hline Vicia hirsuta & 3 & - & pole \\
\hline Vicia sp. & 4 & - & $?$ \\
\hline Xanthium strumarium & - & 1 & vlhkomilné \\
\hline Indet & 13 & - & - \\
\hline Spolu & \multicolumn{2}{|c|}{170} & \\
\hline
\end{tabular}


Tabela 4. Komjatice, poloha Kňazova jama. Základná charakteristika analyzovaných fragmentov mazaníc. Legenda: TS - Triticum spelta; PM - Panicum miliaceum; I - Indet.

\begin{tabular}{|c|c|c|c|c|c|c|c|c|c|}
\hline \multicolumn{7}{|c|}{ Mazanice } & \multicolumn{3}{|c|}{ Otlačky } \\
\hline $\begin{array}{l}\text { Prír. } \\
\text { č. }\end{array}$ & Váha & Tvar/konštrukčný prvok & Org. hmota & Org. charakter & $\begin{array}{l}\text { Farba/ } \\
\text { výpal }\end{array}$ & Hladenie & Plevy & Zrná & Planorastúce \\
\hline 1 & tažká & vel'ký, plochý, zo steny & vel'a & steblá, listy $\geq 100$ & červená & $\begin{array}{l}\text { na jednej strane, } \\
\text { nie rukami }\end{array}$ & $1 \mathrm{TS}$ & $1 \mathrm{PM}$ & - \\
\hline 2 & t’ažká & vel'ký, nepravidelný, z rohu & vela + kamene & steblá, listy $\geq 100$ & červená & na vonkajšej strane & - & - & - \\
\hline 3 & l'ahká & fragment, nepravidelný & vel'a & steblá, listy $\geq 100$ & čierna & $\begin{array}{l}\text { na jednej strane, } \\
\text { nie rukami }\end{array}$ & - & - & $1 \mathrm{I}$ \\
\hline 4 & t’ažká & fragment, nepravidelný & málo + kamene & steblá, listy $\leq 50$ & červená & $\begin{array}{l}\text { na jednej strane, } \\
\text { nie rukami }\end{array}$ & - & - & $1 \mathrm{I}$ \\
\hline 5 & l'ahká & fragment, nepravidelný & málo + kamene & steblá, listy $\leq 50$ & červená & nehladená & $2 \mathrm{TS}$ & - & - \\
\hline
\end{tabular}

prímesí v mazaniciach. Určitou nevýhodou pri pridávaní obilných zŕn, ale aj semien planorastúcich druhov je, že po určitom čase a na miestach, ktoré nie sú dostatočne chránené pred daždovou vodou začnú $\mathrm{v}$ hmote, mazanici (hlina a voda) stavby klíčit, dokonca aj rást. ${ }^{5}$ To môže viest' k narušeniu kompaktnosti mazanice a následnej deštrukcii takto upravených stien. Rozbor sortimentu organického rastlinného materiálu v skúmaných fragmentoch mazaniciach túto možnost’ potvrdzuje. Do mazanicového cesta bola v Komjaticiach väčšinou pridávaná slama (steblá či listy pravdepodobne obilnín), čo dokladá aj nízky počet odtlačkov semien a pliev pestovaných plodín.

Analýza zachovaných fragmentov mazaníc často umožňuje aj skúmanie konštrukčných detailov potenciálnych sídliskových stavieb. Na základe nich možno uvažovat’ aj o potencionálnej rekonštrukcii stavebných techník, použitých pri realizácii jednotlivých sídliskových objektov (Ďuriš 2015). Aj na nepočetných fragmentoch (5 kusov), pochádzajúcich z Komjatíc-Kňazovej jamy, bolo možné identifikovat’ odtlačky po prútenej konštrukcie stien (prípadne stropov) a hladkého výmazu opozitnej strany. Tieto pozorovania potvrdzujú, že aj v prípade sídliskových objektov zo skúmaného laténskeho sídliska boli steny objektov konštrukčne riešené jednoduchou technikou dreveného výpletu. Ten bol z vonkajšej strany prekrytý a zamazaný hrubšou vrstvou hliny s prímesou rôznych organických rastlinných častí. Najmä vd’aka nálezom mazaníc, spolu s pomerne podrobnou kresbovou dokumentáciou preskúmaných laténskych sídliskových objektov, bolo možné vytvorit aj ideálnu rekonštrukciu typického príbytku na tomto sídlisku (Horváth/Látková 2014).

\section{Archeobotanika nížinných sídlisk juhozápadného Slovenska}

V tejto časti je prezentované porovnanie výsledkov archeobotanického materiálu z Komjatíc s inými doposial publikovanými laténskymi lokalitami, prevažne nížinnými sídliskami z juhozápadného Slovenska.

Do súboru skúmaných lokalít v kontexte vzorky z Komjatíc bolo celkovo zaradených 12 laténskych sídlisk z juhozápadného Slovenska. Hodnotené boli len tie lokality, o ktorých existovali informácie o získanom archeobotanickom materiáli, a to minimálne so zoznamom určených rastlinných druhov. ${ }^{6}$ Konkrétne to boli lokality Bernolákovo-Obora 1, Bratislava-Devín hrad, Bratislava-Námestie SNP 29, Bratislava-Podhradie, Bratislava-Trnávka-Silničné, Červeník, Komárno-Námestie Európy, Nitra-hrad, Nitra-Chrenová II. (známa aj ako poloha Staré záhrady), Nitra-Mikov dvor a Nitra-Šindolka (tabela 5). Botanický materiál na týchto lokalitách nebol vo väčšine prípadov súčastou systematického výskumu, skôr šlo o náhodne odoberané vzorky zo „zaujímavých kontextov,“ podobne ako to bolo v prípade vzorky z Komjatíc.

\footnotetext{
5 L. Kupcová, ústna informácia.

6 Za poskytnutie informácií o archeobotanickom materiáli d’akujeme Ing. J. Mihályiovej, AÚ SAV Nitra.
} 
Tabela 5. Zoznam hodnotených lokalít.

\begin{tabular}{|l|c|c|c|c|l|}
\hline \multicolumn{1}{|c|}{ Lokalita } & Kód & Datovanie & $\sum$ vzoriek & $\sum$ RMZ & \multicolumn{1}{|c|}{ Literatúra } \\
\hline Bernolákovo-Obora 1 & BE OB1 & LTC2/D2 & 9 & 15 & Březinová/Dan̆ová 2019 \\
Bratislava-Devín hrad & BA DH & LTC/D & 4 & 1271 & Hajnalová E. 1989 \\
Bratislava-Námestie SNP 29 & BA 29 & LTD & 1 & 13 & Hajnalová E. 1989 \\
Bratislava-Podhradie & BA Pod. & LTD & 1 & 200 & Hajnalová E. 1989 \\
Bratislava-Trnávka-Silničné & BA TRs & LTD & 2 & 14 & Hajnalová/Mihályiová/Hajnalová 20005 \\
Červeník & Čer & LTA & 1 & 5 & Hajnalová E. 1989 \\
Komárno-Námestie Európy & KM NE & LT & 16 & 284 & Hajnalová M. 2001 \\
Nitra-hrad & NR HR & LTD1/D2 & 3 & 267 & Hajnalová/Mihályiová/Hunková 2002 \\
Nitra-Chrenová II & NR CH II & LTB2/D & 1 & 39 & Hajnalová E. 1989 \\
Nitra-Mikov dvor & NR MD & LTB2/D & 3 & 2148 & Hajnalová E. 1989 \\
Nitra-Párovské Háje I & NR PH & LTC1 & 13 & 264 & Benková/Hajnalová/Hunková 1991 \\
Nitra-Šindolka & NR ŠD & LTB2/D1 & 2 & 76 & Hajnalová E. 2000 \\
\hline
\end{tabular}

\section{Plodiny}

Sortiment pestovaných plodín laténskych sídlisk z juhozápadného Slovenska je pomerne bohatý a druhovo rozmanitý.

\section{Obilniny}

Vo všeobecnosti sú na laténskych sídliskách JZ Slovenska najpočetnejšie zaznamenávané obilniny. Na skúmaných lokalitách bolo celkovo doložených osem obilných druhov, ktoré tvoria 3602 zuholnatených nálezov. Zastúpené boli plevnaté pšenice (jednozrnová, dvojzrnová a špaldová) aj nahozrnné obilniny (pšenica siata, raž siata, jačmeň plevnatý aj nahý, ovos; obr. 3). Z toho vyplýva, že na laténskych sídliskách sa nachádzajú druhy obilnín, ktoré boli naviazané na predchádzajúce praveké obdobie a môžu predstavovat kontinuitu tradície pestovania overených druhov. Týka sa to najmä pšenice jednozrnovej, dvojzrnovej a špaldovej, ktoré sú typickými plodinami takmer pre celé obdobie praveku a protohistórie (Hajnalová E. 1993). Za výnimočné v tomto kontexte možno považovat nálezy pšenice dvojzrnovej jednozrnky z Komjatíc. Pri porovnaní skladby obilnín s predošlým obdobím je možné badat určitý vzostup $\mathrm{v}$ prípade nahozrnových plodín a ovsa.

Na sídlisku Červeník (Hajnalová E. 1989, 22), ktorý v súbore predstavuje najstaršiu lokalitu spadajúcu do včasnolaténskeho obdobia, LTA (450-380 pred Kr.), bol zaznamenaný len vel’mi malý počet nálezov obilnín (5 kusov). Na základe takto nízkeho počtu nálezov, ako aj pre chronologickú ojedinelost' lokality, nie je možné určit typické obilniny pre danú dobu a región. Pre toto obdobie je však pre Českú republiku typický výskyt plevnatého jačmeňa a pšenice dvojzrnovej. V prípade moravských lokalít je dominantnou obilninou opät jačmeň (ArboDat; Kočár/Dreslerová 2010, 214-217; Kreuz/Schäfer 2002). Aj tu však platí podobná situácia s len vel'mi malým počtom českých a moravských včasnolaténskych lokalít.

Hodnotenie nasledujúcich chronologických stupňov od obdobia staršej doby laténskej (LTB) až po neskorú dobu laténsku (LTD) je problematické z dôvodu častého viacfázového osídlenia lokalít. Osídlenie na sídliskách je možné rozdelit do troch horizontov (staršiu, strednú a neskorú dobu laténsku).

Starší úsek strednej doby laténskej, LTB2/LTC1-LTC1 (240/230-180 pred Kr.) bol doložený na sídliskách Nitra-Zobor, polohy Šindolka a Martinský vrch, Nitra-Chrenová, polohy II a III, a Nitra-Mikov dvor, poloha Výstavba rozvodne elektriny (Březinová/Chropovský 2020, 71; Mihályiová 2020, 187-190). Pre tieto sídliská je charakteristický pomerne vysoký výskyt plevnatého jačmeňa. Popri ňom však možno už badat’ aj rastúci trend prosa a pšenice siatej. Na lokalite Nitra-Mikov dvor boli objavené aj nálezy pšenice špaldovej. Pri porovnaní vývoja zastúpenia jednotlivých obilných druhov v tomto období s oblastou

\footnotetext{
7 Archeobotanická databáza Českej republiky. https://web.arup.cas.cz/czad/arbodat.php?l=cz
} 


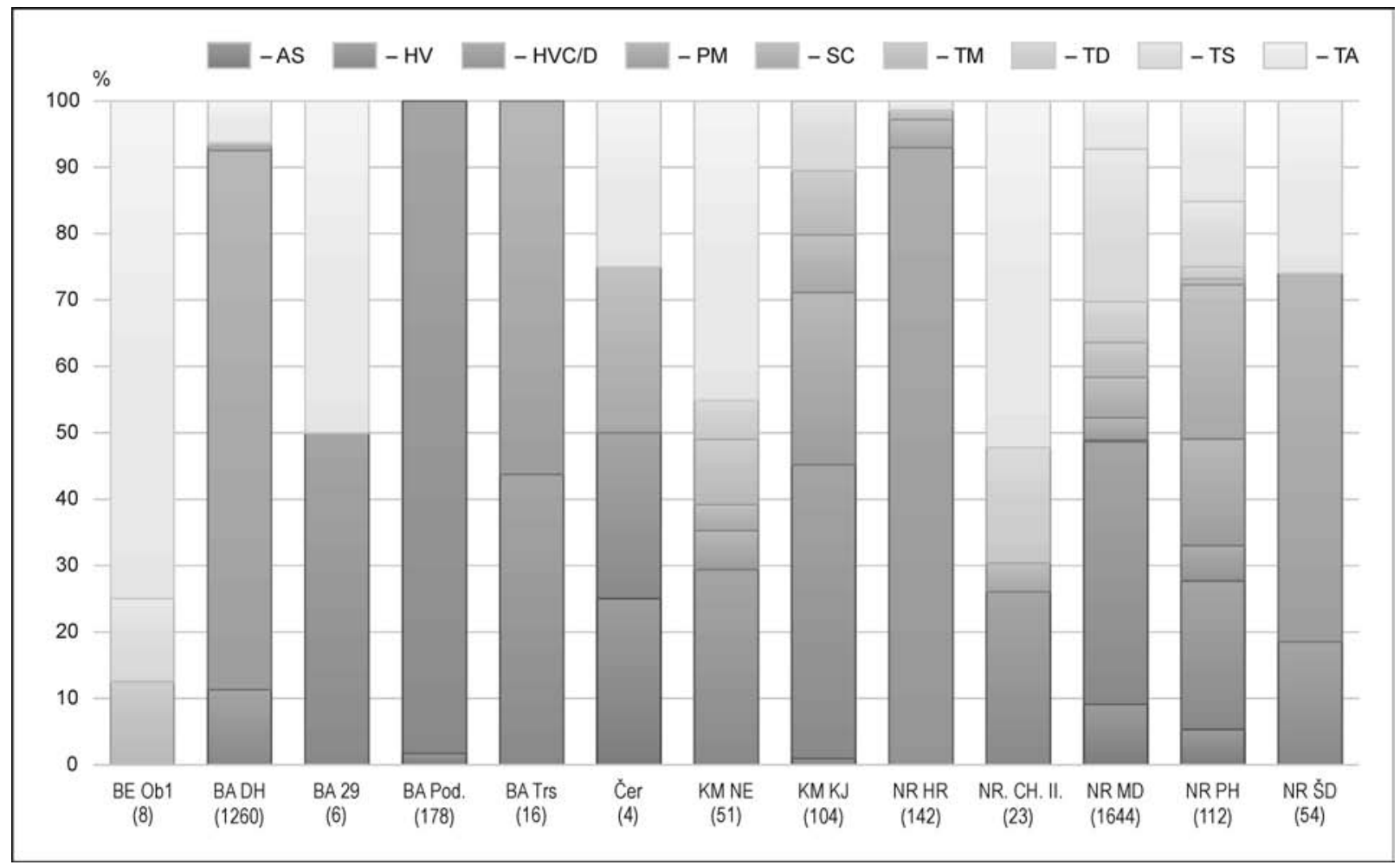

Obr. 3. Pomer obilných druhov uvedených v absolútnom počte po vylúčení všetkých bližšie neidentifikovaných fragmentov, $\mathrm{n}=3286$. Legenda: AS - ovos siaty (Avena sativa); HV - jačmeň plevnatý siaty (Hordeum vulgare-vulgare); HVC/D - jačmen nahozrnový siaty (Hordeum vulgare var. coeleste/distichon); PM - proso siate (Panicum miliaceum); SC raž siata (Secale cereale); TM - pšenica jednozrnová (Triticum monococcum); TD - pšenica dvojzrnová (Triticum dicoccum); TS - pšenica špaldová (Triticum spelta); TA - pšenica siata (Triticum aestivum). Číslo v zátvore vyjadruje počet nálezov.

Čiech a Moravy je možné sledovat vel’mi podobný trend (ArboDat; Kreuz/Schäfer 2002; Kočár/Dreslerová 2010, 214-217).

V mladšom úseku strednej doby laténskej, LTC2-LTC2/D1 (180-130 pred Kr.), pokračuje osídlenie na sídliskách Nitra-Zobor, polohy Šindolka a Martinský vrch, Nitra-Chrenová, polohy II, III a Športový areál, Nitra-Mikov dvor, poloha Výstavba rozvodne elektriny. Na prelome LTC2/D1 tieto sídliská zanikajú (Březinová/Chropovský 2020, 71; Mihályiová 2020, 187-190). Osídlenie je doložené aj na lokalitách Bernolákovo-Obora 1 (Březinová/Daňová 2019, 163), Nitra-Párovské háje I (Benková/Hajnalová/Hunková 1991, 24) a Bratislava-Devín hrad (Hajnalová E. 1989, 21). Najviac nížinných sídlisk pochádza práve zo stredolaténskeho obdobia a z hladiska archeobotanického skúmania ide o momentálne najlepšie zdokumentované obdobie. $V$ tomto období je sortiment obilných druhov vel'mi podobný predošlému. Dominancia pretrváva $\mathrm{v}$ prípade jačmeňa plevnatého a na výraznejšom postavení nadobúdajú proso a pšenica siata. Netypickým je výraznejšie zastúpenie dosial' menej výraznej obilniny, raže siatej, a to na lokalite Nitra-Párovské Háje I. Výskyt plevnantých pšeníc (jednozrnová, dvojzrnová a špaldová) je v hodnotenom súbore lokalít výrazne redukovaný a ich nálezy sú bud' len ojedinelé, alebo úplne absentujú. Na českých lokalitách sú pre toto obdobie dominantnými najmä plevnaté obilniny (pšenica dvojzrnová a špaldová), pričom na moravských je nad’alej dominantnejším plevnatý jačmeň so pšenicou siatou (ArboDat; Kreuz/Schäfer 2002; Kočár/Dreslerová 2010, 214-217). Do tohto časového horizontu patria aj nálezy z Komjatíc. Skúmaná vzorka v tomto kontexte vykazuje isté odlišnosti, a to predovšetkým relatívne širokým a v istom zmysle odlišným spektrom obilnín (pozri vyššie). Prítomné v nej boli ako pre danú dobu "nové“ druhy, tak aj druhy, ktoré v laténskom období neboli doposial na sledovanom území zaznamenané.

Neskorá doba laténska, LTD1-LTD2 (130/115 - 20 rokov pred Kr.), bola potvrdená iba z lokality Nitra-Mikov dvor, v polohe Výstavba rozvodne elektriny, kde sú najmladšie objekty 98/80, 216 a 218/82 (Březinová/Chropovský 2020, 71; Mihályiová 2020, 187-190). Na základe početnosti zastúpenia jednotlivých obilných druhov možno konštatovat', že plevnatý jačmeň si zachováva výraznú dominanciu skoro počas 


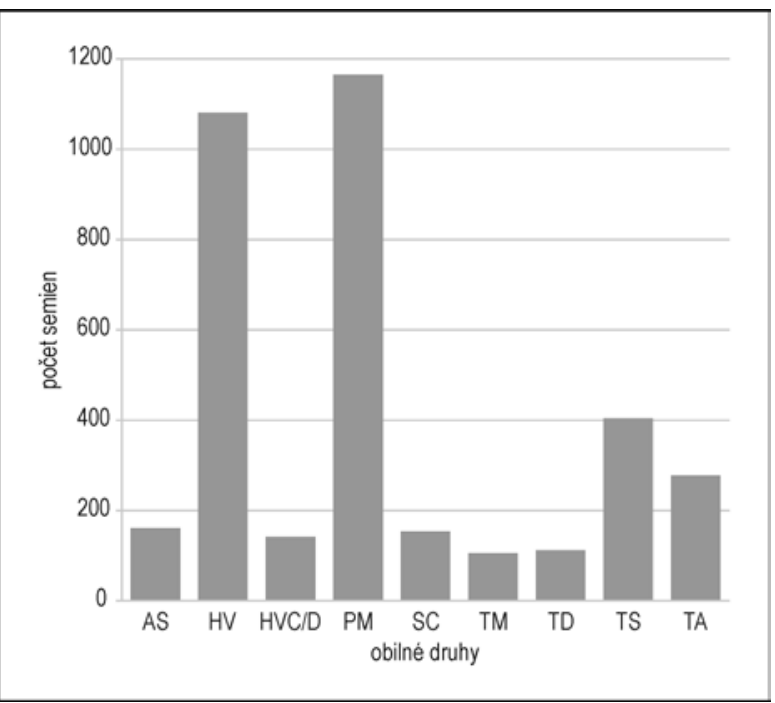

Obr. 4. Výskyt obilných druhov z hladiska ich absolútneho počtu semien. Legenda: pozri obr. 3.

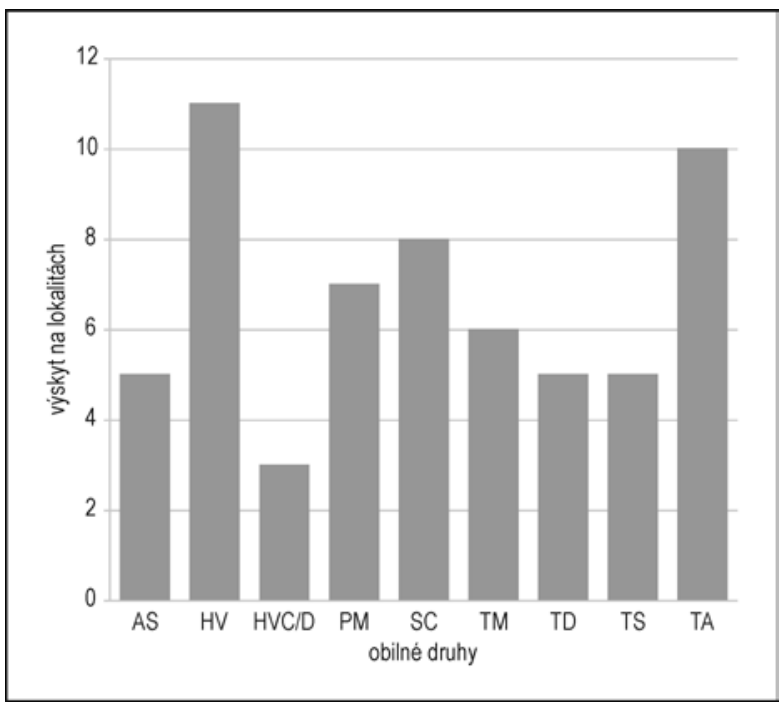

Obr. 5. Výskyt obilných druhov z hladiska ich významnosti (frekvencie výskytu). Legenda: pozri obr. 3.

celého laténskeho obdobia a zastúpený bol takmer na všetkých lokalitách v hodnotenom súbore. Trend určitej prevahy však nadobúdajú nahozrné obilniny voči plevantým. Pre obdobie LTD z územia Českej republiky existuje pomerne málo dát. $V$ oboch regiónoch (Čechy verzus Morava) dominuje pšenica siata. Na Morave má však významné postavenie aj pšenica dvojzrnová, pričom na českých lokalitách je to jačmeň (ArboDat; Kočár/Dreslerová 2010, 214-217; Kreuz/Schäfer 2002).

Pri porovnaní absolútneho počtu nálezov bolo možné sledovat aj výrazné postavenie prosa siateho medzi pestovanými obilninami. Túto interpretáciu však výrazne skresluje ojedinelý hromadný nález z lokality Bratislava-Devín hrad (pozri tabelu 5), ktorý výrazným spôsobom nadhodnotil zastúpenie prosa siateho v skúmanom súbore. Vo všeobecnosti možno konštatovat', že medzi oblúbené chlebové plodiny $\mathrm{v}$ dobe laténskej patrila pšenica špaldová a pšenica siata (obr. 4). Podobne je to aj pri porovnaní poznatkov na českých a moravských lokalitách (ArboDat; Kočár/Dreslerová 2010, 214-217; Kreuz/Schäfer 2002).

Na základe hodnotenia frekvencie výskytu jednotlivých druhov (t. j. počtu vzoriek, v ktorých sa druh nachádza), bez ohl'adu na množstvo nálezov v nich, je na prvom mieste opät jačmeň a za ním nasleduje pšenica siata. Menej často sa vyskytujú proso a uvedená raž siata (obr. 5). Obidve obilniny boli zastúpené v relatívne rovnakom pomere. V sumáre možno z tohto hodnotenia obilnín konštatovat', že sortiment obilnín a zastúpenie jednotlivých druhov na lokalitách odráža istý trend, a to že na sídliskách juhozápadného Slovenska v laténskom období boli uprednostňované nahozrnové obilniny (pšenica siata a raž siata) pred plevnatými (jednozrnka, dvojzrnka a špalda). Toto tvrdenie podporujú aj staršie analýzy rastlinného materiálu doby laténskej (Hajnalová E. 1989; 1993).

\section{Plevy}

Okrem nálezov obilných zín boli pomerne často v skúmanom súbore RMZ prítomné aj nálezy zuholnatených pliev plevnatých pšeníc. Najčastejšie sú zastúpené bazálne časti pliev pšenice jednozrnovej a pšenice špaldovej. Doložené sú aj fragmenty krehkejších pliev, tzv. internódií klasových vretien nahozrnových obilnín (rachis Hordeum/Triticum). Tie sa nachádzajú len v menšom množstve (dôvody pozri vyššie; Boadman/Jones 1990) z hladiska absolútneho počtu, ale aj frekvencie výskytu.

\section{Strukoviny}

Zo strukovín boli najčastejšie, ale aj najpočetnejšie doložené nálezy šošovice kuchynskej, ktorá bola v súbore zastúpená 270 zuholnatenými semenami, pričom zrná šošovice sa nachádzali aj vo väčšom počte vzoriek (7 vzoriek) ako iné druhy, napr. hrach (4 vzorky). Vysoký počet zín šošovice, ktorý tvorí väčšinu všetkých nálezov pochádza z lokality Nitra-Mikov dvor (264 nálezov). Ďalšou najčastejšie zastúpenou 
strukovinou s výrazne nižším počtom nálezov (celkovo 18 kusov) bol hrach siaty. Sortiment strukovín obohacuje (okrem šošovice a hrachu, ktoré patria skôr k „,tradičným“ strukovinám) aj bôb konský (1 kus), ktorý sa vo všeobecnosti radí k menej kvalitným strukovinám (Zohary/Hopf 2000, 112). Na základe jeho pomerne početných nálezov na niektorých lokalitách (v oblasti mimo JZ Slovenska) sa zdá, že zrejme patril k pomerne oblúbením plodinám v sledovanom období (Hajnalová E. 1989, 90).

\section{Technické plodiny}

Vláknodarné (priadne či textilné) a olejnaté plodiny ako l’an a konope sú spravidla doložené na lokalitách len ojedinelými nálezmi. Je to najmä preto, že tieto druhy majú endosperm prirodzene bohatý na olej, ktorý podnecuje horenie. Tak pri ich horení nedochádza ku karbonizácií, ale k úplnému vyhoreniu bez zachovaných častí, prípadne premene na popol. Tieto plodiny boli využívané predovšetkým na získavanie priadze a oleja, no nie je možné v niektorých prípadoch vylúčit ich využitie na prípravu pokrmov či na medicínske účely. $Z$ tejto kategórie bola na skúmaných laténskych sídliskách juhozápadného Slovenska doložená len konopa siata ako jedna zuholnatená „hrudka“ semien z lokality Bratislava-Devín hrad (Hajnalová E. 1989, 21).

\section{Jedlé plody}

Doklady ovocia či iných pochutín, napríklad zeleniny, patria medzi zriedkavé až výnimočné $\mathrm{v}$ pravekých alebo protohistorických archeobotanických súboroch (Hajnalová E. 1989; 2001). Nepočetnost’ týchto nálezov zrejme môže súvisiet’ s ich výrazne odlišnými procesmi exploatácie, uskladnenia a využitia. Z ovocia a zeleniny sa často zachovali len tie časti, ktoré boli tažko konzumovatelné alebo inak d’alej využitelné a tvorili predovšetkým odpady. Najväčší potenciál na zachovanie mali predovšetkým najpevnejšie časti, ktoré v najväčšej miere predstavovali kôstky, v menšej miere stonky, konáriky, listy. Proces prípravy, konzumácie a uskladnenia ovocia či zeleniny bol odlišný a menej náročný, ako to bolo v prípade obilnín. Odpad vznikal skôr pri samotnom skonzumovaní danej plodiny, pričom nie vždy skončil v ohni, ako to bolo $\mathrm{v}$ prípade obilnín, ktorých plevy mohli byṫ využité aj ako odpadový materiál. Ich prítomnost’ však jednoznačne poukazuje na spestrenie jedálnička. Kategóriu ovocia reprezentujú tri nálezy zuholnatených malvíc hrušky zo Šároviec (Hajnalová E. 1989, 25). Pri tomto náleze E. Hajnalová $(1989,90)$ vyslovila predpoklad, že zrejme mohlo íst’ o doklad nejakej divej formy hrušky (zrejme Pyrus pyraster). Nálezy skôr predstavujú doklady zberného hospodárstva ako cieleného pestovania ovocia $\mathrm{v}$ dobe laténskej. Dalším výnimočným nálezom z kategórie ovocia je nález kôstky broskyne, ktorá sa našla na pohrebisku v Palárikove v hrobe dietata (Hajnalová E. 1989, 24). V tomto prípade však možno predpokladat', že ide o doklad importovaného ovocia, prípadne len samotnej kôstky (Hajnalová E. 1989, 90). Vzhladom na jej netypickú vizuálnu stránku mohla slúžit ako ozdoba šiat, alebo bola súčastou šperku (Hajnalová E. 2001, 36).

\section{Planorastúce druhy}

Planorastúce druhy sa vyskytli v súboroch na každej lokalite a boli zachované výlučne karbonizáciou. Spolu je možné hodnotit 487 nálezov, ktoré bolo možné priradit k 42 bližšie determinovaným taxónom. Na základe ich životnej formy (dreviny, byliny a trávy), dnešných ekologických nárokov na stanovište a úžitkovosti či spôsobu využitia sú hodnotené v skupinách, a to ako zbierané plody, polné buriny, ruderály, rastliny lúk a pasienkov, rastliny lesov (v podobe drevín a krovín).

Medzi najpočetnejšie, ale aj najčastejšie vyskytujúce sa druhy paria kategórie polných burín (24 taxónov) a ruderálych-sídliskových (5 taxónov) druhov. Dnes sa tieto druhy zarad’ujú medzi bežné polné a záhradné buriny (napr. Fallopia convolvulus, Galium spurium, Chenopodium album agg.). Zaznamenané tu boli aj rastlinné druhy, ktoré sa dnes na poliach vyskytujú už len ojedinele (napr. Matricaria matricarioides, Bupleurum rotundifolium, Agrostemma githago a Asperula arvensis).

Burinové spoločenstvá reprezentujú zástupcovia, ktorí pochádzajú z polných systémov a najčastejšie sú to buriny jarín, okopanín a rumoviskové buriny. $\mathrm{Z}$ fytocenologického hladiska boli zaznamenané druhy blízke súčasným spoločenstvám Polygono-Chenopodietalia a Sisimbrietalia. Buriny jarín ako Chenopodium album agg., Chenopodium hybridum, Echinochloa crus-galli a Setaria viridis/verticillata pochádzajú často zo spoločenstiev prosných polí, prípadne môže íst̉ aj o polia s oziminami, ktoré však boli na jar okopané alebo inak odburinené (Bogaard 2004, 100; v. der Veen 1992, 131). 
Prítomnoste semien planorastúcich druhov, pochádzajúcich z biotopov mimo polné kultúry, indikuje možnú prítomnosti spoločenstiev teplomilnej ruderálne vegetácie, najmä rôznych skládok či rumovísk. Tie sa nachádzali v blízkosti ludských obydlí, respektíve inak narušovaných pôd pomerne bohatých na živiny. Takéto spoločenstvá reprezentujú aj obnažené dná a brehy vôd či iné vlhké stanovištia, kde rastie napr. Xanthium strumarium. Rumoviskové spoločenstvá s prítomnostou viacročných rastlín, by mohli reprezentovat nálezy Galium spurium. V tomto prípade však nemusia nálezy jednoznačne dokladat' prítomnost' rumoviska, nakol'ko je Galium spurium často zastúpený aj ako burina $\mathrm{v}$ obilných poliach.

V skúmanom súbore boli druhy aj iných spoločenstiev a zbierané plody. Nakol'ko sa však vyskytli iba ojedinele, nebolo by korektné ich interpretovat' komplexnejšie.

\section{DISKUSIA}

Nálezy rastlinných zvyškov, pri správnej metodike odberu a extrakcie, môžu mat’ ovela vyššiu výpovednú hodnotu než len určenie rastlinných druhov. Do istej miery môžu poukazovat aj na rôzne sídelné aktivity, ktoré sa odohrávali na skúmaných sídliskách. Tie možno vysledovat na základe ich spojitosti s rôznymi aktivitami napr. pri procese pozberovej úprave plodín (najmä obilnín), ich skladovania, kuchynskou úpravou a konzumáciou, o ktorých vieme z historických či etnografických prameňov. Cielom takýchto analýz archeobotanických súborov je charakterizovat ich pôvod a definovat pred a po depozičné procesy, ktoré sa podiel’ali na ich vzniku (Dennel 1974; 1976; Hillman 1984). Vo väčšine prípadov archeologické zuhol'natené rastlinné makrozvyšky pochádzajú z rôznych krokov pozberovej úpravy plodín a z toho dôvodu je nutné pokúsit sa určit', ku ktorému konkrétnemu kroku ich možno priradit (v. der Veen 1992, 81, 82). Súčasný stav publikovaného archeobotanického materiálu z laténskych lokalít, kde neraz absentujú základné informácie o charaktere a pôvode každej jednej vzorky, nateraz nedovoluje aplikovat’ na materiál tafonomické analýzy. Tafonomická analýza v archeobotanike totiž musí prebiehat na úrovni vzorky, a teda každého jedného kontextu/nálezovej situácie. Publikované lokality sú však často charakterizované len sumárnym počtom nálezov jednotlivých druhov a v niektorých prípadoch sú iba konštatovaním o prítomnosti daného druhu. Takto publikované lokality sú nepoužitelné pre komplexnejšie hodnotenie chronologických fáz či geografických celkov. Ďalšie (paleo)ekonomické hodnotenie laténskych lokalít je nutné zamerat' na riešenie otázky, kde a či sa na sídliskách mohli nachádzat’ archeobotanické nálezy, ktoré by dokladali miestnu produkciu pol’nohospodárskych plodín, alebo nálezy, ktoré by dokladali konzumáciu plodín produkovaných (pestovaných a upravovaných) na inom mieste. Tafonomická a ekonomická analýza súborov RMZ by mohla indikovat sociálny status skúmaných lokalít (v zmysle konzumný verzus produkčný Hillman 1981; 1984; Jones 1984). Archeobotanický materiál môže indikovat’ aj schopnosti mobilizácie pracovnej sily pri produkcii plodín (Fuller/Stevens 2009). Takto získané poznatky by bolo možné d’alej porovnávat’ $\mathrm{v}$ rámci chronologických stupňov, geografických celkov, prípadne v závislosti od typu sídlisk. Z literatúry sú známe analýzy, kde boli aplikované uvedené metódy, avšak ide o výhradne výšinné lokality. Prípadová archeobotanická štúdia laténskeho oppida, Liptovská Mara, od M. Hajnalovej (1999), ktorá bola zameraná aj na skúmanie tafonomických procesov na lokalite, dokladá také súbory, ktoré reprezentujú finálne, ale aj počiatočné fázy procesu spracovania plodín (Hajnalová M. 1999, 52). Z toho vyplýva, že na lokalite sa pravdepodobne odohrával celý proces pozberovej úpravy plodín. Liptovská Mara je v odbornej literatúre označovaná ako hospodárske a kultúrne centrum Liptova s vlastnou remeselnou výrobou (Pieta 1996, 47-79). Na základe uvedených charakteristík, ktoré sú odvodené od archeologických nálezov, je oprávnený predpoklad, že miestni obyvatelia so svojimi elitami boli skôr konzumentmi a polnohospodárske produkty sa na lokalitu dostávali ako protihodnota za iné služby, ktoré poskytovali takéto centrá (napr. ochrana, odbytiská pre výrobky, náboženstvo, administratíva a atd’.). Napriek tomu, že použité metódy a modely pri klasifikácii archeobotanických vzoriek majú isté úskalia, pri aplikácii a interpretácii výsledkov samotných tafonomických analýz je zrejmé, že aj lokality centrálneho významu ako Liptovská Mara si určité plodiny (obilniny a strukoviny) pestovali a dalej spracovávali (čistili) sami (Hajnalová M. 1999, 61). Jednoduché členenie na konzumné alebo produkčné lokality, z hladiska produkcie potravín rastlinného pôvodu, má však aj svoje jemné nuansy. Medzi produkčnými aj konzumnými typmi lokalít sú aj také, ktoré len čiastočne zapadajú do takejto klasifikácie. Produkčné lokality možno delit d’alej na lokality produkujúce si pre vlastnú spotrebu (malá polnohospo-

\footnotetext{
8 Tento problém sa, bohužial', netýka len lokalít mladšej doby železnej, ale celého pravekého či stredovekého obdobia.
} 
dárske usadlosti) alebo na väčšie usadlosti produkujúce tzv. nadhodnotu (v. der Veen 1992, 360). Z územia Českej republiky možno spomenút podobnú prípadovú štúdiu s iným metodologickom postupom. Tá bola zameraná na objasnenie vztahu oppida Staré Hradisko k okolitým sídliskám v zázemí. Na základe hodnotenia rôznych environmentálnych premenných sa ukázalo, že uvedené laténske oppidum nie je možné považovat’ za výhradne konzumnú lokalitu (Danielisová/Hajnalová M. 2014, 422, 423). V súčasnosti je v odbornej literatúre vidiet̉ značný trend odklonu od predstavy, kedy boli oppidá považované za vývojový vrchol, a to v sociálnom, ekonomickom a politickom vývoji. Taktiež sa upúšta od predstavy, že oppidá boli len miestom spotreby hospodárskych produktov (potraviny rastlinného, ale aj živočíšneho pôvodu). Boli však schopné podielat sa na získavaní potravín a exploatáciu zdrojov z okolitej krajiny pre svoju vlastnú spotrebu (pozri napr. Collis 2000, 236; Danielisová/Hajnalová M. 2014, 407, 408; Küster 1991, 426, 427; Wells 1993, 139; Woolf 1993, 214). Aj vd’aka súčasným moderným archeobotanickým štúdiám možno uvažovat', že sledované lokality ako nižinné vidiecke osady, tak aj výšinné centrá, mali plnohodnotne rozvinutú produkciu pol’nohospodárskych plodín (obilnín a strukovín).

\section{ZÁVER}

Prezentovaná analýza a interpretácia súborov RMZ z laténskych lokalít juhozápadného Slovenska, s akcentom na lokalitu Komjatice-Kňazova jama, obsahovala spolu 5698 rastlinných makrozvyškov (semien). Cielom bolo konfrontovat získané výsledky s inými podobnými lokalitami a definovat' spektrum úžitkových rastlín (pestovaných aj planorastúciach), hl’adat trendy v ich výskyte na lokalitách, respektíve zmeny sortimentu $\mathrm{v}$ čase. Z pestovaných rastlín su na hodnotených laténskych lokalitách najpočetnejšie obilniny $(3602 \mathrm{ks})$. Dominantné postavenie v súbore má $\mathrm{z}$ hladiska počtu aj frekvencie výskytu plevnatý jačmeň. Za ním nasleduje pšenica siata, pšenica špaldová, proso, raž a pšenica dvojzrnová. V súbore strukovín (289 ks) sa našli tri druhy, a to šošovica kuchynská, hrach siaty a bôb konský. Spektrum obilnín, strukovín a kombinácia druhov vo vzorkách je takmer rovnaká na všetkých skúmaných lokalitách a v časových fázach. V stredolaténskom období je však badatelná istá inovácia v polnohospodárstve. Prejavuje sa nárastom nálezov nahozrnovej pšenice na úkor plevnatých pšeníc a zavedením dvoch nových plodín, raže a ovsa, do pestovania. Získaný sortiment pestovaných plodín z juhozápadného Slovenska viac inklinuje k súdobým moravským lokalitám ako k českým (ArboDat; Kočár/Dreslerová 2010, 214-217; Kreuz/Schäfer 2002), čo logicky vychádza z geografických, ale aj environmentálnych podmienok. Na nížinných laténskych sídliskách (nateraz) chýbajú výraznejšie doklady tzv. luxusných plodín a pochutín (ovocia a zeleniny), ktoré by indikovali ich dovoz/pestovanie a konzumáciu. Pri porovnaní skúmaného súboru planorastúcich druhov zo vzorky z Komjatíc-Kňazovej jamy s nálezmi na iných stredolaténskych nížinných sídliskách v regióne juhozápadného Slovenska možno konštatovat', že predstavujú typickú skladbu, nijak výrazne odlišnú od iných lokalít. Aj celkový charakter nálezov RMZ v skúmanej vzorke plne zapadá do kontextu plodín využívaných v skúmanom období. Avšak aj sortiment základných plodín (obilnín a strukovín), zaznamenaný v nálezoch z ostatných lokalít juhozápadného Slovenska v plnom rozsahu, zapadá do obrazu, ktorý je známy pre obdobie mladšej doby železnej. Súčasné archeobotanické zistenia taktiež neindikujú, že by obyvatelia žijúci v opevnených a výšinných lokalitách (v tomto kontexte najmä Liptovská Mara, Bratislava-Devín hrad a Nitra hrad) mali odlišné, resp. iné potravinové stratégie ako obyvatelia žijúci v nížinných neopevnených sídliskách. V d’alšom bádaní je potrebné zamerat’ sa na detailnejšie archeobotanické skúmanie laténskych lokalít, venovat dostatočnú pozornost̉ metodike vzorkovania archeologických kontextov a zvýšit intenzitu preplavovania uloženín sídliskových objektov. Až konfrontácia a porovnanie nových súborov RMZ môže prispiet’ k riešeniu náročnejších otázok subsitenčných stratégií bežných vidieckych sídlisk doby laténskej.

\section{LITERATÚRA}

Anderberg 1994

Benková/Hajnalová/Hunková 1991

Berggren 1969
A. L. Anderberg: Atlas of seeds and small fruits of Northwest-European plant species (Sweden, Norway, Denmark, East Fennoscandia, Iceland) 4. Resedaceae-Umbelliferae. Stockholm 1994.

M. Benková/E. Hajnalová/E. Hunková: Archeobotanické nálezy v Nitre-Párovských Hájoch a ich vyhodnotenie. Agrikultúra 23, 1991, 7-30.

G. Berggren: Atlas of seeds and small fruits of Northwest-European plant species with morphological descriptions 2. Cyperaceae. Stockholm 1969. 
Berggren 1981

Boardman/Jones 1990

Bogaard 2004

Březinová/Daňová 2019

Březinová/Chropovský 2020

Collis 2000

Danielisová/Hajnalová 2014

Dennel 1974

Dennel 1976

Dostál/Červenka 1991

Dostál/Červenka 1992

Ďuriš 2015

Fuller/Stevens 2009

Hajnalová E. 1989

Hajnalová E. 1993

Hajnalová E. 2000

Hajnalová E. 2001

Hajnalová M. 1999

Hajnalová M. 2001

Hajnalová M. 2012

Hajnalová/Dreslerová 2010

Hajnalová/Hajnalová 1998

Hajnalová/Mihályiová/Hajnalová 2005

Hajnalová/Mihályiová/Hunková 2002

Hillman 1981

Hillman 1984

Horváth 2014

Horváth/Látková 2014
G. Berggren: Atlas of seeds and small fruits of Northwest-European plant species with morphological descriptions 3. Salicaceae-Cruciferae. Stockholm 1981.

S. Boardman/G. Jones: Experiments on the effects of charring on cereal plant components. Journal of Archaeological Science 17, 1990, 1-11.

A. Bogaard: Neolithic Farming in Central Europe. Routledge London 2004.

G. Březinová/K. Daňová: Sídlisko z doby laténskej v Bernolákove. In: I. Bazovský/G. Březinová (ed.): Ludia a hory - archeologická perspektíva. Interakcie l'udských spoločenstiev horských a podhorských oblastí západného Slovenska. Zborník SNM. Archeológia. Supplementum 12. Bratislava - Nitra 2019, 153-178.

G. Březinová/B. Chropovský: Sídliská z doby laténskej v Nitre. ASM Fontes 27. Nitra 2020.

J. Collis: "Celtic" Oppida. In: M. H. Hansen (ed.): A comparative Study of Thirty City-State Cultures. An Investigation Conducted by the Copenhagen Polis Centre. Historisk-filosofiske Skrifter 21. Copenhagen 2000, 229-239.

A. Danielisová/M. Hajnalová: Oppida and agricultural production - state of the art and prospects. Case study from the Staré Hradisko oppidum (Czech Republic). In: S. Hornung (ed.): Produktion - Distribution - Ökonomie. Siedlungs und Wirtschaftmuster der Latènezeit. Kolloquium Otzenhausen 2011. Universitätsforschungen zur prähistorischen Archäologie. Bonn 2014, 407-428.

R. W. Dennel: Botanical evidence for prehistoric crop processing activities. Journal of Archaeological Science 1, 1974, 275-284.

R. W. Dennel: The economic importance of plant resources represented on archaeological sites. Journal of Archaeological Science 3, 1976, 229-247.

J. Dostál/M. Červenka: Vel'ký klúǔ na určovanie rastlín I. Bratislava 1991.

J. Dostál/M. Červenka: Vel’ký klúč na určovanie rastlín II. Bratislava 1992.

J. Ďuriš: Architektúra domu mladšej a neskorej doby kamennej na juhozápadnom Slovensku na základe analýzy mazanice. Nitra 2015.

D. Q. Fuller/C. J. Stevens: Agriculture and the Development of Complex Societies: An Archaeobotanical Agenda. In: A. S. Fairbairn/E. Weiss (ed.): From foragers to farmers. Papers in honour of Gordon C. Hillman. Oxford 2009.

E. Hajnalová: Súčasné poznatky z archeobotaniky na Slovensku. Acta Interdisciplinaria Archaeologica 6. Nitra 1989.

E. Hajnalová: Obilie v archeobotanických nálezoch na Slovensku. Acta Interdisciplinaria Archaeologica 8. Nitra 1993.

E. Hajnalová: Archäbotanische funde aus der latènezeit von der fundstelle Nitra-Šindolka. In: G. Březinová: Nitra-Šindolka. Siedlung aus der Latènezeit. Katalog. Nitra 2000, 295-298.

E. Hajnalová: Ovocie a ovocinárstvo v archeobotanických nálezoch na Slovensku. Acta Interdisciplinaria Archaeologica 10. Nitra 2001.

M. Hajnalová: Osada a životné prostredie severných Karpát na počiatku doby dejinnej. Dizertačná práca (Prírodovedecká fakulta Univerzity Komenského v Bratislave). Bratislava 1999. Nepublikované.

M. Hajnalová: Rastlinné makrozvyšky analyzované v roku 2000. AVANS 2000, 2001, 82-83.

M. Hajnalová: Archeobotanika doby bronzovej na Slovensku. Nitra 2012.

M. Hajnalová/D. Dreslerová: Ethnobotany of einkorn and emmer in Romania and Slovakia: towards interpretation of archaeological evidence. Památky archeologické 101, 2010, 169-202.

E. Hajnalová/M. Hajnalová: Preplavovanie-Metóda získavania rastlinných makrozvyškov z archeologických objektov a vrstiev. Informátor SAS 8, 1998, 6, 7 .

E. Hajnalová/J. Mihályiová/M. Hajnalová: Nové archeobotanické poznatky. AVANS 2005, 2007, 77-83.

E. Hajnalová/J. Mihályiová/E. Hunková: Archeobotanické nálezy rastlinných zvyškov z lokality Nitra-hrad. Študijné zvesti AÚ SAV 34, 2002, 205-278.

G. Hillman: Reconstructing Crop Husbandry Practices from Charred Remains of Crops. In: R. Mercer (ed.): Farming practice in British prehistory. Edinburgh 1981, 123-162.

G. Hillman: Interpretation of archaeological plant remains: The application of ethnographic models from Turkey. In: W. van Zeist/W. A. Casparie (ed.): Plants and ancient man. Studies in palaeoethnobotany. Rotterdam 1984, 1-41.

P. Horváth: Laténske sídlisko v Komjaticiach, poloha Kňazova jama. Študijné zvesti Aú SAV 56, 2014, 69-110.

P. Horváth/M. Látková: Komjatice „Kňazova jama“ Možnosti rekonštrukcie laténskej chaty s jej hospodárskym zázemím. In: Experimentálna archeológia, činnost’ 
Jacomet 2006

Jones 1984

Kočár/Dreslerová 2010

Kreuz 2005

Kreuz/Boenke 2002

Kreuz/Schäfer 2002

Küster 1991

Küster 1993

Mihályiová 2020

Nesbitt/Samuel 1996

Pieta 1996

Točík 1980a

Točík $1980 b$

Točík 1981

Točík 1978

v. der Veen 1992

v. der Veen 1999

Wells 1993

Willcox 2003

Willerding 1971

Woolf 1993

v. Zeist 1968

v. Zeist 1999

Zohary/Hopf 2000 archeoparkov a popularizácia archeológie. Zborník referátov z konferencie v Hanušovciach nad Toplou, 26.-27. 6. 2014. Hanušovce nad Toplou 2014, 27-32.

S. Jacomet: Identification of cereal remains from archaeological sites $\left(2^{\text {nd }} \mathrm{ed}\right.$.). Dostupné na: http://ipna.unibas.ch/archbot/pdf/Cereal_Id_Manual_engl.pdf

G. E. M. Jones: Interpretation of archaeological plant remains: Ethnographic models from Greece. In: W. van Zeist/W. A. Casparie (ed.): Plants and ancient man. Studies in paleoethnobotany. Rotterdam 1984, 43-61.

P. Kočár/D. Dreslerová: Archeobotanické nálezy pěstovaných rostlin v pravěku České republiky. Památky archeologické 101, 2010, 203-242.

A. Kreuz: Landwirtschaft im Umbruch? Archäobotanische Untersuchungen zu den Jahrhunderten um Christi Geburt in Hessen und Mainfranken. Bericht der Römisch-Germanischen Kommission 85, 2005, 97-292.

A. Kreuz/N. Boenke: The presence of two-grained einkorn at the time of the Bandkeramik culture. Vegetation History and Archaeobotany 11, 2002, 233-240.

A. Kreuz/E. Schäfer: A new archaeobotanical database programme. Vegetation History and Archaeobotany 11, 2002, 177-179.

H. Küster: L'agriculture. In: Les Celtes. Milano 1991, 426-428.

H. Küster: The carbonized plant remains. In: Wells 1993, 57-60.

J. Mihályiová: Archeobotanické nálezy v objektoch z doby laténskej v Nitre. Archaeologica Slovaca Monographiae Fontes 27. Nitra 2020, 185-191.

M. Nesbitt/D. Samuel: From staple crop to extinction? The archaeology and history of the hulled wheats. In: S. Padulosi/K. Hammer/J. Heller (ed.): Hulled wheats. Proceedings of the First International Workshop on Hulled Wheats. Promoting the conservation and use of underutilized and neglected crops 4. Tuscany 1996, 41-100.

K. Pieta: Liptovská Mara, včasnohistorické centrum severného Slovenska. Archeologické pamätníky Slovenska 5. Bratislava 1996.

A. Točík: Výsledky prieskumu archeologických lokalít na juhozápadnom Slovensku. AVANS 1978, 1980, 266-272.

A. Točík: Pokračovanie záchranného výskumu v polohe Kňazova jama v Komjaticiach. AVANS 1979, 1980, 215-229.

A. Točík: Záverečná správa zo záchranného výskumu v Komjaticiach v rokoch 1977 a 1979. Študijné zvesti Aú SAV 19, 1981, 139-157.

A. Točík: Záchranný výskum v Komjaticiach. AVANS 1977, 1978, 246-272.

M. van der Veen: Crop Husbandry Regimes. An archaeobotanical study of farming in northern England 1000 BC-AD 500. Sheffield 1992.

M. van der Veen: The economic value of chaff and straw in arid and temperate zones. Vegetation History and Archaeobotany 8, 1999, 211-224.

P. S. Wells: Settlement, Economy and Cultural Change at the End of the European Iron Age. Excavations at Kelheim in Bavaria, 1987-1991. International Monographs in Prehistory. Archaeological Series 6. Ann Arbor 1993.

G. Willcox: Chalcolithic carbonised cereals from Ubaid burntstorage structures at Kosak Shamali. In: Y. Nishiaki/T. Matsutani (ed.): Tell Kosak Shamali. Vol. II. Tokyo 2003, 267-270.

U. Willerding: Methodische Probleme bei der Untersuchung und Auswertung von Pflanzenfunden in vor- und frühgeschichtlichen Siedlungen. Nachrichten Niedersachsen Urgesch 40, 1971, 180-198.

G. Woolf: The social significance of trade in late Iron Age Europe. In: C. Scarre/ F. Healy (ed.): Trade and Exchange in Prehistoric Europe. Proceedings of a Conference held at the University of Bristol, April 1992. Oxford 1993, 211-218.

W. A. van Zeist: Prehistoric and early historic food plants in the Netherlands. Palaeohistoria 14, 1968, 42-173.

W. A. van Zeist: Evidence for agricultural change in the Balikh basin, northern Syria. In: C. Gosden/J. Hather (ed.): The prehistory of food. Appetites for change. London 1999, 350-373.

D. Zohary/M. Hopf: Domestication of Plants in the Old World 3. Oxford 2000. 


\title{
The results of archaeobotanical analysis from the site Komjatice-Kňazova jama in the context of La Tène settlements from Slovakia
}

\author{
Michaela Látková - Peter Horváth
}

Summary

The article presents an analysis and interpretation of 5698 plant macro-remains (PMR) from an opened (non-fortified) La Tène settlement site of Komjatice-Kňazova jama (south-western Slovakia) and confronts the results with other 12 opened settlement sites from this lowland region the aim was to define the assortment of cultivated and wild plants and to look for possible trends in their spatial and temporal occurrence. It was also hoped to apply the method of taphonomic analyses on the plant macro-remains assemblages from the region and interpret the results in terms of subsistence strategies. Consequently, to discuss the results in relation of the existing hypothesis of subsistence of the upland and or fortified sites such as the late La Tèneoppida.

Of the cultivated plants, the most numerous cereals in the evaluated La Tène localities (3602 pcs). Barley (Hordeum vulgare) has a dominant position in terms of number and ubiquity (frequency) of finds. It is followed by free-threshing wheat (Triticum aestivum s.l.), spet wheat (Triticum spelta), broomcorn millet (Panicum miliaceum), rye (Secale cereale) and two-grained einkorn (Triticum monococcum 2g). Among pulses (289 pcs), three species were found - lentil (Lens culinaris), sweet pea (Pisum sativum) and celtic bean (Vicia faba). Cereals and legumes and the combination of species in the samples is similar in all evaluated sites and across the phases of the La Tène period. However, the more emphasis on consumption of free-threshing wheat and introduction of new crops like rye and oat into cultivation is recorded since the middle La Tène period. The assortment of cultivated crops from south-western Slovakia is more similar to contemporary Moravia than to Czech sites (Kočár/Dreslerová 2010, 214-217), which clearly derives from more similar cultural, geographical as well as environmental setting. Even though, the assortment of staple crops (cereals and legumes) recorded in southwestern Slovakia fully fits the picture known for the Late Iron Age in wider central Europe, there is no evidence on use and or cultivation of exotic or luxury crops (fruits and vegetables)or condiments as documented for example in nearby Austria (site of Roseldorf).

The available data on plant macroremians from La Tène settlement sites in south-western Slovakia lack necessary detail for taphonomic analyses and consequent economic interpretation. Yet the findings do not indicate that the inhabitants living in fortified hilltop sites within lowland region (Bratislava-Devín hrad) or in the uplands of Northern Slovakia (Liptovská Mara), have had differentfood subsistence strategies than those living in lowland unfortified settlements. In the future research, it is necessary to focus on more vigorous sampling, floatation and more detailed archaeobotanical examination of La Tène settlement sites to obtain representative assmblages which could verify this hypothesis.

Fig. 1. Komjatice, site Kňazova jama. Ratio of main components (cultivated crops, husks and wild species). Legend: a cultivated crops; $\mathrm{b}$ - cereal husks; c - wild species.

Fig. 2. Komjatice, site Kňazova jama. Ratio of the main components of selected specific species (cultivated crops and cereal husks). Legend: AS - Avena sativa; HV - Hordeum vulgare; PM - Panicum miliaceum; SC - Secale cereale; TM - Triticum monococcum; TS - Triticum spelta; H/T - Hordeum/Triticum; a - cereals; b - husks.

Fig. 3. Ratio of cereal species indicated in absolute numbers after exclusion of all unidentified fragments, $\mathrm{n}=3286$. Legend: AS - oats (Avena sativa); HV - barley (Hordeum vulgare-vulgare); HVC/D - naked barley (Hordeum vulgare var. coeleste/distichon); PM - millet (Panicum miliaceum); SC - ray (Secale cereale); TM - single grain eincorn (Triticum monococcum); TD - emmer (Triticum dicoccum); TS - spelled wheat (Triticum spelta); TA - bread wheat (Triticum aestivum). The number in parentheses represents the number of findings.

Fig. 4. Occurrence of cereal species in terms of their absolute number of seeds. Legend: as in Fig. 3.

Fig. 5. Occurrence of cereal species in terms of their significance (frequency of occurrence). Legend: as in Fig. 3.

Tab. 1. Komjatice, site Kňazova jama. List of cereals assortment.

Tab. 2. Komjatice, site Kňazova jama. List of cereal husks.

Tab. 3. Komjatice, site Kňazova jama. Wild species.

Tab. 4. Komjatice, site Kňazova jama. Basic characteristics of the analyzed fragments of daub. Legend: TS - Triticum spelta; PM - Panicum miliaceum; I - Indet.

Tab. 5. The list of evaluated sites.

Mgr. Michaela Látková, PhD.

Archeologický ústav AV ČR, Brno v. v. i.

Mikulčice 736

CZ - 69619 Mikulčice

latkova@arub.cz
Mgr. Peter Horváth, PhD.

Dvorní 56

Lužice

CZ - 69618 Lužice

et_mawerick@gmail.com 